\title{
Polymorphisms in Nucleotide Excision Repair Genes and Risk of Colorectal Cancer: A Systematic Review
}

\author{
Rikke Dalgaard Hansen and Ulla Vogel \\ Danish Cancer Society \& National Research Centre for the Working Environment
}

Denmark

\section{Introduction}

Various DNA alterations can be caused by exposure to environmental and endogenous carcinogens through direct binding of metabolites (adduct formation). If not repaired the DNA lesions may lead to genetic instability, mutagenesis and oncogenesis. Thus, DNA repair constitutes a first line of defence against cancer.

Environmental factors are likely to cause damage to DNA through direct binding of metabolites (adduct formation). The nucleotide excision repair (NER) pathway is the primary mechanism for removal of large and bulky adducts from DNA.

\subsection{Single nucleotide polymorphisms}

Common occurring single nucleotide polymorphisms (SNPs) in genes involved in DNA repair may possibly contribute to the variation in the capacity of repair of bulky DNA adducts. Hence, these SNPs may be important biomarkers of susceptibility to cancer.

The present book chapter includes a systematic review of the available scientific literature on associations between SNPs in genes involved in NER and risk of colorectal adenomas and colorectal cancer. The present review of colorectal cancer studies includes 19 studies on 22 different SNPs. The review is focused on SNPs in four genes: XPD, XPC, XPA and ERCC1 encoding the essential components of NER: xeroderma pigmentosum complementation group $\mathrm{A}, \mathrm{C}$, and $\mathrm{D}$ and excision repair cross complementary group 1 and risk of colorectal adenomas and colorectal cancer, and on interaction between the polymorphisms and various life style factors in relation to colorectal cancer risk.

The NER polymorphisms studied in the work underlying this book chapter include the polymorphisms: XPD Lys751Gln, XPD Asp312Asn, XPA G23A, XPC Lys939Gln, and ERCC1 Asn118Asn.

\subsection{Colorectal cancer}

Colorectal cancer is the third most common cancer and the leading cause of cancer deaths in Western industrialised countries. Thus, every year nearly one million people worldwide develop colorectal cancer. Lifetime risk of colorectal cancer may reach $6 \%$ of the population in the Western industrialised countries (Jemal et al., 2006). The age-specific incidence of colorectal cancer increases sharply after 35 years of age, with approximately $90 \%$ of cancers 
occurring in persons older than 50 years (Schottenfeld \& Winawer, 1996). The mean age at time for diagnosis in Danish colorectal cancer patients is approximately 70 years for men and 72 years for women (Iversen et al., 2005) . The disease develops either sporadically, as a part of a hereditary cancer syndrome, or induced by inflammatory bowel disease. Ten to fifteen percent of colorectal cancer cases are caused by hereditary syndromes (Schottenfeld \& Winawer, 1996) .

Migrant studies and large international variation in incidence rates indicate that life style factors, including dietary, are associated with risk of colorectal cancer, but traditional epidemiological studies based on life style questionnaires and outcome have mostly failed in identifying the exact risk and beneficial factors. Our current knowledge of colorectal carcinogenesis indicates a multi-factorial and multi-step process that involves various genetic alterations and several biological pathways. An understanding of differences in individual susceptibility and better exposure assessment may be crucial in identifying life style risk factors and possible interactions between susceptibility and exposures in relation to risk of colorectal cancer.

\section{DNA adducts}

Several life style factors and dietary components are suggested to be associated with risk of colorectal cancer, listed in Table 1 . The associations may possibly be caused by increased formation of DNA adducts.

\subsection{NOC, HCA and PAH}

$\mathrm{N}$-nitroso compounds (NOCs) are present in tobacco smoke and in nitrate- or nitrite-treated meats (Hotchkiss, 1989; Hecht \& Hoffmann, 1988). NOCs are alkylating agents able to react with DNA and form adducts. More than $85 \%$ of 300 NOCs tested for carcinogenicity in experimental animals were observed to be carcinogenic (Mirvish, 1995), but epidemiologic studies have been inconclusive in finding association between the exposure of NOCs and risk of various cancer forms in humans (Burch et al., 1987; Preston-Martin \& Mack, 1991; Carozza et al., 1995), although an increased endogenous production of NOCs, suggested primarily by bacterial catalysis, are proposed associated to the etiology of colorectal cancer (Bingham et al., 1996).

Polycyclic aromatic hydrocarbons (PAHs) and heterocyclic aromatic amines (HCAs) constitute a major class of chemical carcinogens present in the environment. When metabolically activated, these compounds act as mutagens and carcinogens in animal models (Culp et al., 1998; Moller et al., 2002; Dingley et al., 2003) and are able to form bulky DNA adducts in humans (Hecht, 2003), (Phillips, 2002). Many PAHs and HCAs are found to be tumourigenic in humans or experimental animals (International Agency for Research on Cancer (IARC), 1983). Cooking meat at high temperatures and certain preservation and processing procedures leads to the formation of PAHs and HCAs (Sinha et al., 2005; Guillen et al., 1997) . PAHs are ubiquitous environmental contaminants formed by incomplete combustion of organic matter. They are one of several classes of carcinogenic chemicals present in tobacco smoke (Benhamou et al., 2003; Melikian et al., 1999). PAH compounds may not only be formed by high cooking temperatures but are also found in uncooked food, like sea food and plants, due to contamination of the aquatic environment (Meador et al., 1995) or via atmospheric exposure (Guillen et al., 1997). 


\subsection{Life style factors and DNA adduct formation}

Air pollution is not an established risk factor for colorectal cancer in humans, although several studies have shown higher risk among workers exposed to diesel exhaust (Goldberg et al., 2001). Some studies have found an association between ambient air pollution and DNA adduct levels (Poirier et al., 1998; Hemminki et al., 1990b; Binkova et al., 1995; Palli et al., 2001; Nielsen et al., 1996a; Nielsen et al., 1996c), whereas others failed to find such an association (Kyrtopoulos et al., 2001; Peluso et al., 1998). DNA adduct levels are increased following occupational exposure among foundry and coke oven workers and among workers exposed to diesel exhaust (Hemminki et al., 1997; Hemminki et al., 1990a; Hemminki et al., 1994; Perera et al., 1988; Perera et al., 1994; Lewtas et al., 1997; Nielsen et al., 1996a; Nielsen et al., 1996b), while among fire-fighters (Rothman et al., 1993), traffic exposed policemen (Peluso et al., 1998) and aluminium workers (Yang et al., 1998), no associations between occupational exposures and DNA adducts have been found.

Tobacco smoking is an established risk factor for development of adenomas (Ji et al., 2006), and recently an association between tobacco smoking and risk of colorectal cancer has been recognized by IARC. Following tobacco smoking, adducts formed by metabolites of NOCs and PAHs are not only located in airway tissue, but are also found in bladder and cervical tissue from smokers (Benhamou et al., 2003; Melikian et al., 1999).

\begin{tabular}{l|cl} 
Life style factor & Risk of CRC & DNA adduct formation \\
\hline Air pollution & $\uparrow$ & PAH \\
Tobacco smoking & $\uparrow$ & PAH, NOC \\
Alcohol & $\uparrow$ & Acetaldehyde \\
Red meat & $\uparrow$ & PAH, NOC, HCA \\
Processed meat & $\uparrow$ & PAH, NOC, HCA \\
Vegetables & $\downarrow$ & - \\
Fruit & $\downarrow$ & - \\
\hline
\end{tabular}

Table 1. Possible environmental risk and beneficial factors of colorectal cancer and their association with DNA adduct formation. Arrows indicate adverse $(\uparrow)$ or preventive $(\downarrow)$ association with risk of colorectal cancer.

A growing body of evidence supports that avoidance of alcohol is recommended to prevent colorectal cancer (Correa Lima \& Gomes-da-Silva, 2005). Acetaldehyde is the primary oxidative metabolite of ethanol. Acetaldehyde and malondialdehyde, the end-product of lipid peroxidation by reactive oxygen species, can combine to form the malondialdehydeacetaldehyde adduct, which is very reactive and avidly binds to DNA (Brooks \& Theruvathu, 2005). The level of acetaldehyde DNA adducts in white blood cell DNA in alcohol abusers have been measured up to 13-fold higher than in subjects from the nondrinking control group (Fang \& Vaca, 1997). 
There is some evidence for adverse associations between intake of red and processed meat and risk of colorectal cancer (Johnson \& Lund, 2007; Doyle, 2007; Norat et al., 2005). The elevated risk may be due to an increased endogenous production of NOC, which may enhance the colonic formation of the DNA adduct O6-carboxymethyl guanine (Bingham et al., 1996; Lewin et al., 2006). Cooking meat at high temperatures leads to the formation of polycyclic aromatic hydrocarbons (PAHs) and heterocyclic amines (HCAs) (Sinha et al., 2005). Additionally, intake of charbroiled or smoked meat may be associated with increased levels of DNA adducts (Rothman et al., 1990; van Maanen et al., 1994; Georgiadis et al., 2001; Rothman et al., 1993), due to HCAs and PAHs (Bruemmer et al., 1996; Balbi et al., 2001; Peters et al., 2004; Skog et al., 1995). The levels of some HCAs and PAHs are comparable for red meat, fish and poultry smoked or cooked at high temperatures (Sinha et al., 1995; Gomaa et al., 1993). Intake of red meat, but not of fish and poultry, increases the luminal contents of N-nitrosocompounds (NOCs) in colon (Bingham et al., 1996; Lewin et al., 2006). The increase in endogenous $N$-nitrosation can be attributed to heme iron (Cross et al., 2003), which is 10-fold higher in red meat than in white meat (Pierre et al., 2003).

There is limited evidence for a preventive effect of intake of fruit and vegetables for cancer in colon and rectum (International Agency for Research on Cancer (IARC), 2003). Intake of fruit, vegetables or antioxidant vitamins have been shown to be negatively associated with DNA adduct levels (Palli et al., 2000; Mooney et al., 1997; Palli et al., 2003; Palli et al., 2004), although some studies found no effect (Georgiadis et al., 2001; Nielsen et al., 1996b) and one study found an effect of increased vitamin intake only in females (Mooney et al., 2005).

\section{Nucleotide excision repair}

The nucleotide excision repair (NER) pathway is the primary mechanism for removal of helix-distorting damages from DNA, including bulky adducts and UV-induced photolesions. The mechanism of NER includes five steps: 1. Damage recognition, 2. Assembly of the repair factors at the site of damage, 3. Dual incisions and excision of the damage-containing oligomers, 4 . Resynthesis to fill in the gap, and 5. Ligation of the strands. All these steps involve more than 20 proteins, like recognition factors, replication protein, transcription factor, helicases, endonucleases and polymerases. Steps 1 and 2 are illustrated in Figure 1.

\subsection{The NER pathway}

There are two sub-pathways of NER, termed the global genome NER (GG-NER), which corrects lesions in the entire genome including the non-transcribed strands of active genes, and transcription-coupled NER (TC-NER), that only repairs lesions in transcribed strands in active genes. The major differences of the two pathways are the damage recognition step: In GG-NER the proteins Xeroderma Pigmentosum complementation group A and C (XPA/XPC) make the recognition complex (Hanawalt, 2002; Reardon \& Sancar, 2002; You et al., 2003; Volker et al., 2001), while in TC-NER a stalled RNA polymerase II (blocked by a lesion) and Cockayne syndrome proteins have this function to act as a signal to recruit NER proteins (Kobayashi et al., 2005; Hanawalt, 2002).

In global genomic NER the XPA and XPC enzymes are involved in the damage recognitioncomplex of NER. Several studies have shown the XPC-hHR23B complex to function at a very early stage of DNA damage recognition (Reardon \& Sancar, 2002; You et al., 2003; 
Hanawalt, 2002; Volker et al., 2001). The hHR23B (also called Rad23) NER factor co-purifies with XPC (Masutani et al., 1994) and is essential for high XPC activity in NER (Batty et al., 2000; Guzder et al., 1998). XPC-hHR23B complex exhibit a very strong affinity for damaged DNA (Reardon et al., 1996; Batty et al., 2000; Sugasawa et al., 1998), why it is thought to be the initiator in GG-NER. By interaction with the XPC complex XPA and the transcription factor II H (TFIIH) may be recruited to the damaged DNA site (You et al., 2003; Volker et al., 2001). TFIIH is a nine sub-unit protein complex required for opening the DNA helix at the vicinity of the lesion (Schaeffer et al., 1993; Feaver et al., 1993; Drapkin et al., 1994). Biochemical studies have generated conflicting results with regard to association between the XPC-hHR23B complex, XPA and TFIIH. Some have found recruitment of TFIIH to the site of DNA damage to be dependent on XPC (Volker et al., 2001; Yokoi et al., 2000), while others have found XPA to be interacting with TFIIH (Park et al., 1995). Undoubtedly, both XPC and XPA are vital factors in the very early steps of GG-NER, but exactly when

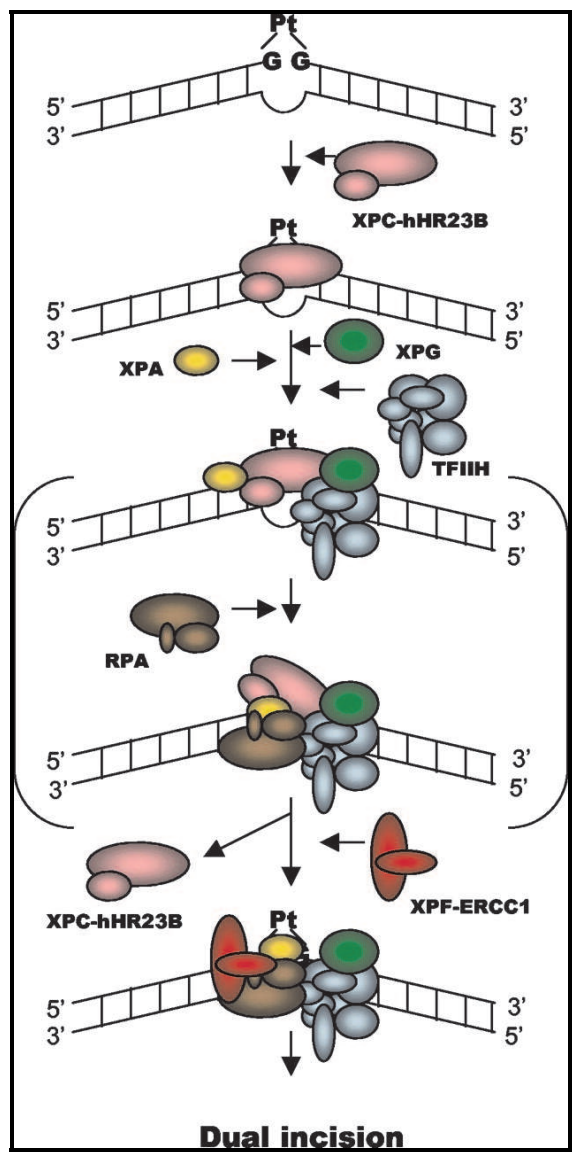

Fig. 1. A proposed molecular mechanism of damage recognition process in the early stage of global genome nucleotide excision repair. Transient steps are indicated with brackets. Adapted from (You et al., 2003) . 
XPA enters the site of damage is not clear. XPA physically interacts with replication factor A (RPA) and is essential to efficient NER (Stigger et al., 1998) by stabilizing the interaction between XPA and the damaged DNA. XPA is capable of binding to the XPF-ERCC1 complex with very high affinity (Park \& Sancar, 1994). The XPF-ERCC1 is a specific 5' endonuclease complex, and thus must be located near the site of $5^{\prime}$ incision (Niedernhofer et al., 2001). XPG, a 3' endonuclease, seems to be the next factor recruited to the site, and is probably positioned at the 3' incision site (Reardon \& Sancar, 2002). Previous studies have observed XPG to co-purify with TFIIH, like XPC, and that XPG exclude XPC when binding to TFIIH (Wakasugi \& Sancar, 1999; Wakasugi \& Sancar, 1998), which may suggest that the binding of XPG to the NER complex displaces XPC. Hence, XPA is thought to be crucial to the subsequent positioning of the involved NER enzymes by binding to XPF-ERCC1 complex and possibly recruit XPG to the site of DNA damage. XPD and XPB are helicases and parts of the large TFIIH complex. They participate in the unwinding of helix in opposite directions of the region of damaged DNA (Reardon \& Sancar, 2002; Schaeffer et al., 1993). When the DNA around the DNA lesion is unwound, the endonucleases XPG and XPFERCC1 complex excises an oligonucleotide of 24-32 bases including the damaged site $(\mathrm{Mu}$ et al., 1996). The two endonucleases require an opening of approximately 5-8 bases (Evans et al., 1997; de Laat et al., 1998). The final steps of NER are re-synthesis of the strand to fill in the gap and ligation of the new strand with the remaining strand. In mammals the synthesis requires the DNA polymerases $\delta$ and/or $\varepsilon$ (Hunting et al., 1991; Coverley et al., 1992), the replication protein A (RPA) and replication factor C (RFC) (Shivji et al., 1995) and proliferating cell nuclear antigen (PCNA) (Shivji et al., 1992). The XPF-ERCC1 5' incision leaves a hydroxyl-group at the $3^{\prime}$ terminus of the gap. This terminus may act as a DNA primer for DNA polymerases (Sijbers et al., 1996). RPA is required for the gap-filling DNA synthesis (Shivji et al., 1995), possibly to protect the template strand against nucleases, and RFC and PCNA as a complex that facilitates the assembly of the polymerases (Shivji et al., 1992). The new fragment of DNA is synthesized and the final step is ligation of the new patch to the original sequence, which possibly may be performed by DNA ligase I (Tomkinson \& Levin, 1997).

\subsection{SNPs in NER genes and colorectal cancer risk}

The variant alleles of XPA G23A (Wu et al., 2003), XPD Asp312Asn and XPD Lys751Gln (Spitz et al., 2001; Qiao et al., 2002) polymorphisms and a polymorphism in XPC (Qiao et al., 2002), in full linkage disequilibrium with the XPC Lys939Gln polymorphism (Khan et al., 2000), have been associated with a lowered DNA repair capacity compared to the wild type allele. ERCC1 gene polymorphism is a predictor for clinical outcome in advanced colorectal cancer patients treated with platinum-based chemotherapy (Viguier et al., 2005). Furthermore, the variant alleles of the polymorphisms XPD Asp312Asn and XPD Lys751Gln have been associated with higher DNA adduct levels (Hou et al., 2002; Matullo et al., 2001; Palli et al., 2001) than the wild type alleles.

Mutations in the NER gene XPD are associated with the rare, autosomal-recessive inherited disorder Xeroderma Pigmentosum, where patients suffer from severe photosensitivity and actinic changes leading to early onset of skin cancers induced by sunlight (Cleaver, 2005). Recently the first case of human inherited ERCC1 deficiency was reported (Jaspers et al., 2007). Cells from the patient showed moderate hypersensitivity to ultraviolet rays, but the clinical features were very severe and compatible with a diagnosis of cerebro-oculo-facio- 
skeletal syndrome. This discovery represents a novel complementation group of patients with defective NER and suggests novel functions for ERCC1.

Overall, the above mentioned studies of the polymorphisms in the genes involved in NER, XPD Lys751Gln, XPD Asp312Asn, XPA G23A, XPC Lys939Gln, and ERCC1 Asn118Asn, indicate that the polymorphisms may modulate DNA repair capacity and may thereby possibly be associated with development of cancer.

There are limited numbers of studies of NER genes in relation to risk of colorectal cancer. A search on the PubMed database of NCBI on January 26th 2011 on the MeSH terms "polymorphism, single nucleotide AND colorectal neoplasms" resulted in 148 hits of which seven studies included polymorphisms in XPD, XPA, XPC, and ERCC1. In combination with a new search on the PubMed database of NCBI by using different combinations of the words: "XPD XPA XPC ERCC1 polymorphism colorectal colon rectum cancer" 19 studies of SNPs in the four genes in relation to risk of colorectal cancer or prestages to colorectal cancer were identified. The studies are listed in Table 2.

\subsubsection{XPD Lys751GIn and XPD Asp312Asn}

The XPD Lys751Gln polymorphism is the most frequently studied of the NER polymorphisms in association with risk of cancer. In our Danish prospective study on the Diet, Cancer and Health cohort, we observed no association of the XPD Lys751Gln and XPD Asp312Asn polymorphisms with risk of colorectal cancer (Hansen et al., 2007). Previously, several studies had similar findings of no association between the XPD Lys751Gln (Moreno et al., 2006; Huang et al., 2006; Berndt et al., 2006; Mort et al., 2003; Starinsky et al., 2005; Skjelbred et al., 2006b; Engin et al., 2010; Stern et al., 2009; Stern et al., 2007; Yeh et al., 2005; Joshi et al., 2009; Wang et al., 2010) and the XPD Asp312Asn (Moreno et al., 2006; Huang et al., 2006; Berndt et al., 2006; Goodman et al., 2006; Stern et al., 2009; Stern et al., 2007; Joshi et al., 2009) polymorphisms and risk of colorectal cancer. Additionally, Bigler and colleagues found no association of the two polymorphisms with development of adenomas (Bigler et al., 2005). However, they detected a higher risk of colorectal adenomas among individuals with at least two variant alleles of the XPD polymorphisms, with an OR of 1.57 (CI: 1.04-2.38). When stratifying by age the association of the two polymorphisms with risk of adenomatous polyps was restricted to the individuals younger than 60 years when diagnosed (OR=3.77, CI: 1.94-7.35). The risk of adenomatous polyps was higher among smokers carrying the homozygous XPD variant alleles (OR=3.93, OR: 1.68-9.21) compared with non-smokers carrying the homozygous wild type. A similar finding could not be detected on risk of hyper-plastic polyps. In our Danish study (Hansen et al., 2007) and in a Singapore Chinese study (Stern et al., 2007) did neither of the two XPD polymorphisms, XPD Lys751Gln or XPD Asp312Asn, modify the effect of smoking on risk of colorectal cancer.

Goodman et al., did not detect any SNP-SNP interaction between the XPD Asp312Asn polymorphism and other NER polymorphisms (Goodman et al., 2006). Skjelbred and colleagues detected an association between the XPD Lys751Gln polymorphism and development of colorectal adenomas, with an OR of 1.40 (CI: 1.08-1.81), among carriers of the variant allele compared to carriers of the homozygous wild type allele (Skjelbred et al., 2006b). The statistical significance was limited to the low-risk adenoma group (OR: 1.46, CI: 1.11-1.90). The results were contradicted by a large study by Stern et al., including 740 cases with adenomas and 789 controls, where a lower risk of adenomas was observed $(\mathrm{OR}=0.7, \mathrm{CI}$ : 
0.4-1.0) among homozygous carriers of the XPD 751Gln allele (Stern et al., 2006). The result was not stratified for ethnicity (Caucasian, African-American, Latinos, Asian-Pacific Islander). When excluding the 1 case and the 17 controls of Latinos, the OR increased to 0.9 (confidence intervals were not reported). An interaction between the XPD Lys751Gln polymorphism and alcohol consumption was observed $(\mathrm{P}=0.04)$, with higher risk of adenomas among ever-drinkers carrying the XPD $751 \mathrm{Gln} / \mathrm{Gln}$ genotype (OR=2.5, CI: 1.25.2) compared with never-drinkers carrying the same genotype. There was no interaction between the polymorphisms XPD Lys751Gln or XPD Asp312Asn, respectively, and alcohol consumption on risk of colorectal cancer in our Danish study (Hansen et al., 2007) and in the Singapore Chinese study (Stern et al., 2007).

In a family-based case-control study using a case-only design, an interaction was observed between the two polymorphisms, XPD Lys751Gln and XPD Asp312Asn, and intake of heavily browned red meat on colorectal cancer risk (Joshi et al., 2009). Intake of red meat heavily brown on the outside or inside increased the risk for colorectal cancer only among carriers of the XPD codon 751 Lys/Lys genotype or the XPD codon 312 Asp/Asp genotype (case-only interaction $\mathrm{P}<0.006$ ). There was no association between the meat intake and colorectal cancer risk when the individuals carried at least one copy of the Asn ${ }^{321}$ or Gln ${ }^{751}$ alleles. The results remained statistically significant after accounting for multiple testing. No interaction was observed in our Danish study between the two XPD polymorphisms and intake of red meat on risk of colorectal cancer (Hansen et al., 2007).

A higher risk of colorectal cancer has been observed among Ashkenazi Jews below 50 years of age when diagnosed (Starinsky et al., 2005). The risk was higher among carriers of the XPD 751Gln allele, but it may be a chance finding due to low number of cases (only 15 cases were diagnosed before their 50 years birthday). Furthermore, the Ashkenazi population is known to have particular genetic characteristics, why the result may not be generalized to other populations.

A large study from Taiwan observed a non-significant tendency for higher risk of colorectal cancer among men carrying the XPD 751Gln allele (OR=1.5, CI: 0.9-2.3), while no association was observed for women (OR=0.9, CI: 0.6-1.5) (Yeh et al., 2007). A similar tendency for a gender specific effect of the XPD Lys751Gln polymorphism was observed in our Danish study, with lower risk of colorectal cancer among women carrying the variant allele of XPD Lys751Gln with an IRR less than 0.62 among carriers of the XPD 751Gln allele, compared to women carrying the wild type allele (Hansen et al., 2007) . No association was found among men. The gender differences could hypothetically be caused by a hormonal interaction. However, we observed no interaction between the use of hormone replacement therapy among women and the polymorphism. Thus, we did not find the hypothesis plausible and conclude that our result in the Danish study may be a chance finding.

\subsubsection{XPC Lys939GIn}

In our Danish study and in a Turkish study by Engin et al. (Engin et al., 2010), the XPC Lys939Gln polymorphism was not associated with risk of colorectal cancer (Hansen et al., 2007). However, we did observe an interaction between the polymorphism and intake of red meat, with an IRR of 3.70 (CI: 1.70-8.04) for colorectal cancer per 100g red meat intake per day among homozygous carriers of the XPC Lys939Gln variant allele (Hansen et al., 2007). In the light of the sample size and the multiple comparisons being made, this result may be a chance finding. The association was not statistically significant after a Bonferroni correction. 
In a large American study by Huang three polymorphisms in XPC was studied, including the XPC Lys939Gln polymorphism. No association was found between the XPC Lys939Gln polymorphism and risk of adenomas (Huang et al., 2006). However, higher risk for development of adenomas was observed among current or recent smokers carrying the XPC 939Gln allele $(\mathrm{OR}=2.0, \mathrm{CI}$ : 1.3-3.0) or a XPC haplotype encompassing three linked SNPs in XPC (Arg492His, Ala499Val, Lys939Gln) compared with neversmokers carrying the homozygous wild type allele. A study by Joshi et al. observed no association between the XPC intron 11 polymorphism and risk of colorectal cancer (Joshi et al., 2009) .

In a small study by Berndt et al. a tendency for higher risk of proximal colon cancer was observed among homozygous carriers of the variant XPC Lys939Gln allele, with an OR of 1.74 (CI: 0.98-3.08) (Berndt et al., 2006). The result may possibly be a chance finding due to sample size and multiple testing. Three other SNPs in the XPC gene, see Table 2, were not associated with colorectal cancer risk.

\subsubsection{XPA G23A}

To our knowledge, only three studies have been published on the association of polymorphisms in the XPA gene with risk of colorectal cancer: The studies by Berndt et al., Joshi et al., and our study. For a polymorphism positioned in the XPA 5' UTR region, a lower risk for colon cancer cancer was observed among carriers of the T-allele $(\mathrm{OR}=0.4,95 \%$ CI: 0.2-0.8) compared with homozygous carriers of the C-allele (Joshi et al., 2009) . There was no association for risk of rectal cancer. No association was observed of the XPA G23A polymorphism (Hansen et al., 2007) or a polymorphism in the 3' un-translated region of XPA (Berndt et al., 2006) with risk of colorectal cancer.

\subsubsection{ERCC1 Asn118Asn}

The results from studies by Skjelbred et al. (Skjelbred et al., 2006a), Joshi et al. (Joshi et al., 2009) , and our Danish study (Hansen et al., 2008) on the ERCC1 Asn118Asn polymorphism suggest no association with risk of colorectal cancer.

Moreno et al. examined five polymorphisms in the ERCC1 gene. A haplotype containing the minor allele of three of the ERCC1 polymorphisms was associated with a higher risk of colorectal cancer (OR=2.3, 95\% CI: 1.0-5.3) compared with carriers of the most frequent haplotype (Moreno et al., 2006). Two other SNPs in the ERCC1 gene were not associated with risk of colorectal cancer (Mort et al., 2003; Berndt et al., 2006).

\subsection{SNPs in NER and risk of other types of cancer than colorectal cancer}

Numerous association studies of polymorphisms in genes involved in NER are reported on various types of cancer, with the majority of studies focused on the XPD Lys751Gln and XPD Asp312Asn polymorphisms. A meta-analysis of lung cancer by Kiyohara et al. (with 1913 cases and 1882 controls of different ethnicities) (Kiyohara \& Yoshimasu, 2007) suggested among other studies (Xing et al., 2002; Hu et al., 2004; Yin et al., 2006), that carriers of the variant alleles of either of the two XPD polymorphisms were found to be at higher risk of lung cancer, while a number of other studies did not observe any association of the two polymorphisms with lung cancer risk (De et al., 2007; Vogel et al., 2005b; Popanda et al., 2004; Hu et al., 2006). 


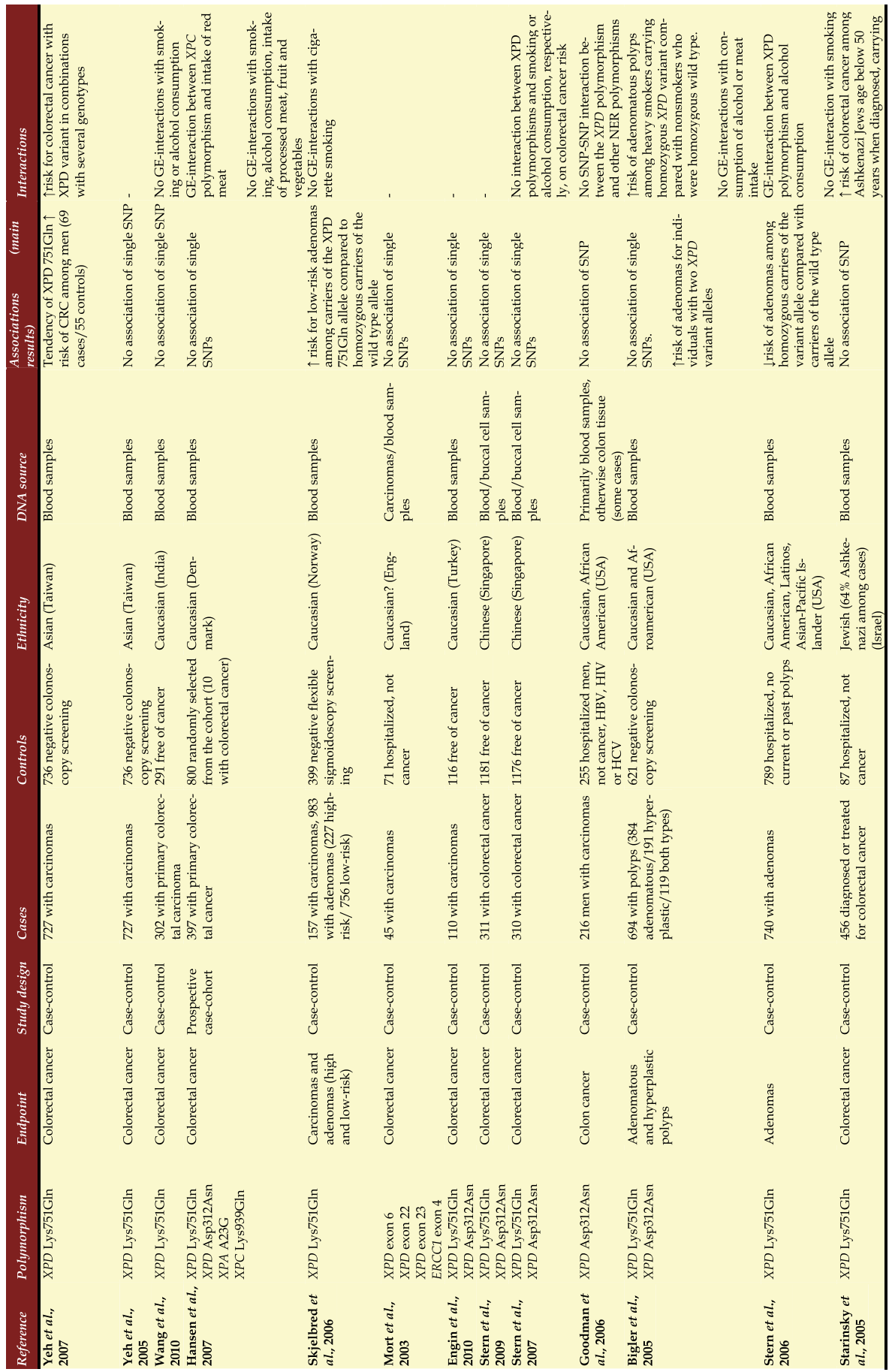


Two large meta-analyses (with 3725 cases and 4152 controls) included identical nine casecontrol studies but made two dissimilar conclusions: The XPD Lys751Gln and XPD Asp312Asn polymorphisms are associated with risk of lung cancer (Hu et al., 2004) or no clear association was found (Benhamou \& Sarasin, 2005). Some studies suggest an interaction between the two XPD polymorphisms and smoking in relation to risk of lung cancer (De et al., 2007; Hu et al., 2006; Xing et al., 2002).

Combinations of the XPD, XPC and XPA genotypes, variant alleles, is suggested to be associated with higher risk of lung cancer (Vogel et al., 2005b). This may be plausible but in the light of multiple testing and the low number of cases this may be a chance finding. The largest breast cancer studies by the number of individuals, 1053 cases/1102 controls (Terry et al., 2004) and 1830 cases/1262 controls (Debniak et al., 2006) observed modest associations of the XPD polymorphisms with breast cancer risk. Carriers of the variant XPD Lys751Gln allele was associated with a $20 \%$ higher risk (OR=1.21, CI: 1.01-1.44) compared with homozygous carriers of the wild type allele. The risk seemed limited to those with a PAHDNA adduct level above the median, with an OR of 1.61 (CI: 0.99-2.63) among homozygous carriers of the XPD 751Gln allele (Terry et al., 2004). Several other studies observed no association of the XPD Lys751Gln polymorphism (Debniak et al., 2006; Dufloth et al., 2005; Brewster et al., 2006; Costa et al., 2007; Mechanic et al., 2006; Jorgensen et al., 2007) or the XPD Asp312Asn polymorphism (Mechanic et al., 2006; Forsti et al., 2004)to risk of breast cancer. However, higher risk has been detected among ever smoking women carrying the XPD 751Gln allele (OR=2.52, CI: 1.27-5.03) compared to ever smoking women carrying the homozygous wild type allele (Metsola et al., 2005). Association with breast cancer risk has been detected when the homozygous variant XPD Lys751Gln allele and the homozygous variant XPD Asp312Asn allele segregated together, with $\mathrm{OR}=1.5(\mathrm{p}<0.05)$ and $\mathrm{OR}=3.69$ (CI: 1.76-7.74), respectively (Debniak et al., 2006; Justenhoven et al., 2004). A large study including 2485 cases with single primary melanoma and 1238 cases with second or higher order primary melanomas detected higher melanoma risk among homozygous carriers of the variant XPD Lys751Gln allele (OR=1.4, CI: 1.1-1.7) or the variant XPD Asp312Asn allele (OR=1.5, CI: 1.2-1.9), respectively (Millikan et al., 2006). Similar results were obtained in a study by Li et al. (Li et al., 2006b), while another study observed the inverse association for both polymorphisms (Han et al., 2005). When stratifying by age Baccarelli et al. observed an association of the two XPD polymorphisms to risk of melanoma only among the individuals older than 50 years when diagnosed (Baccarelli et al., 2004). The XPD Lys751Gln (Andrew et al., 2006) and the XPD Asp312Asn polymorphism (Wu et al., 2006) have been associated with risk of bladder cancer. An interaction is suggested between the XPD Lys751Gln polymorphism and smoking in relation to bladder cancer risk (Andrew et al., 2006; Stern et al., 2002; Schabath et al., 2005). Individuals carrying both the variant XPD alleles were more susceptible to development of bladder cancer (Wu et al., 2006; Andrew et al., 2006) than carriers of wild type alleles. The XPD Lys751Gln and XPD Asp312Asn polymorphisms have not been associated to risk of basal cell carcinoma (Vogel et al., 2005a; Festa et al., 2005; Han et al., 2005; Lovatt et al., 2005), endometrial cancer (Weiss et al., 2006) prostate cancer (Ritchey et al., 2005) or gastric cancer (Huang et al., 2005).

A small study suggest that the variant allele of the polymorphism XPC Lys939Gln is associated with higher risk of bladder cancer (OR=1.49, CI:1.16-1.92) (Sanyal et al., 2004). No association is observed between the polymorphism and risk of lung cancer (Vogel et al., 2005b; Lee et al., 2005; Hu et al., 2006) but a haplotype encompassing more polymorphisms in XPC may contribute to a higher risk of lung cancer (Vogel et al., 2005b; Lee et al., 2005; 
$\mathrm{Hu}$ et al., 2006): Individuals with both putative genotypes of XPC Lys939Gln and XPC Ala499Val polymorphisms are observed with a 2.4-fold (OR=2.37, CI: 1.33-4.21) higher risk of lung cancer compared with individuals with both wild type genotypes (Vogel et al., 2005b; Lee et al., 2005; Hu et al., 2006), with the higest risk observed among smokers. Polymorphisms in XPC have not been associated to risk of basal cell carcinoma (Festa et al., 2005; Nelson et al., 2005), cutaneous melanoma (Blankenburg et al., 2005; Li et al., 2006a) or breast cancer (Mechanic et al., 2006; Jorgensen et al., 2007; Forsti et al., 2004). A lower risk of endometrial cancer may be associated with carriage of at least one variant allele for both XPC Lys939Gln and XPC Ala499Val polymorphisms (Weiss et al., 2005).

In a Korean population carriers of the wild type allele $(\mathrm{G} / \mathrm{G}$ or $\mathrm{A} / \mathrm{G})$ in the XPA G23A polymorphism were reported to have a lower risk of lung cancer compared to carriers of the A/A genotype, with an OR of 0.56 (CI:0.35-0.90) (Park et al., 2002). Similar results were obtained in studies on lung cancer risk in Caucasians and Mexican-Americans (Vogel et al., 2005b; Wu et al., 2003) (Popanda et al., 2004), while a Norwegian study observed the inverse effect with a 1.6-fold higher risk (OR=1.59, CI:1.12-2.27) of lung cancer among carriers of the G/G genotype compared with carriers of the A-allele (Zienolddiny et al., 2006). When stratifying by smoking status the protective effect for lung cancer was only observed among ever smokers (Wu et al., 2003) or current smokers (Park et al., 2002) carrying at least one Gallele or the $G / G$ genotype, respectively. A tendency for lower risk of basal cell carcinoma has been observed among carriers of the variant G-allele, with an OR of 0.82 (CI: 0.66-1.01) and an OR of 0.74 (CI: 0.53-1.03) for homozygous and heterozygous carriers, respectively (Miller et al., 2006). The same tendency was observed for risk of squamous cell carcinoma (Miller et al., 2006). Carriage of at least one A-allele for XPA G23A was associated with decreased risk of endometrial cancer, $\mathrm{OR}=0.47$ (CI:0.25-0.82) compared with carriers of the G/G genotype, but only among women with a history of using oral contraceptives (Weiss et al., 2006).

The ERCC1 Asn118Asn polymorphism is not associated with testicular cancer (Laska et al., 2005). Furthermore, no association has been observed for the ERCC1 Asn118Asn polymorphism to risk of endometrial cancer (Jo et al., 2007; Weiss et al., 2006), ovarian cancer (Jo et al., 2007) and adult glioma (Wrensch et al., 2005).

All in all the studies suggest that the two XPD polymorphisms at amino acid position 312 or 751, the XPD Lys751Gln in particular, are associated with risk of cancer in the lung, breast and bladder and seems to modify the effect of smoking on risk of the three cancer forms. The XPC Lys939Gln polymorphism may possibly be associated with risk of bladder cancer, and the XPA G23A polymorphism may be associated with risk of skin cancer (basal cell carcinoma), endometrial cancer and lung cancer. However, the studies are few and the results are inconsistent.

\section{Discussion}

In summary, this review, limited by the bias against publication of null findings, highlights the complexities inherent in epidemiological research and, particularly, in molecular epidemiological research on colorectal cancer. Studies on possible associations between SNPs in genes involved in defence of oxidative DNA damages and in nucleotide excision repair and risk of colorectal cancer have not obtained consistent results, why the issue of whether the SNPs are possible biomarkers of susceptibility for colorectal cancer is not satisfactorily clarified at present. 
Sample size coupled with allele frequency may have influenced the validity of the results. Differences in the study design, like distribution of gender, age, topology, ethnicity and criteria for recruitment of comparison individuals may have contributed to the dissimilar findings. The application of large, well-designed association studies of the polymorphisms will make it statistically reasonable to make stratified analyses for obtaining information on risk factors in sub-groups and will generally decrease the risk of chance findings. Furthermore, studies including both cases with pre-stages of colorectal cancer and cancer cases will contribute with valuable information of the processes during colorectal carcinogenesis.

Most of the studies analyze individual polymorphisms in genes with modest effect in relation to risk of cancer. Cancer is a complex multigenic and multistage disease involving the interplay of many genetic and environmental factors. Hence, it is unlikely that a single genetic polymorphism in low-penetrance genes would have a dramatic effect on cancer risk. More information may be obtained from haplotyping multiple polymorphisms within genes or from combining multiple polymorphisms within pathways. The continued advances in SNP maps and in high-throughput genotyping methods will facilitate these analyses. Defining haplotypes and whole genome association studies may yield information on unexplored regions of the genome that has impact on colorectal cancer risk and development. Colorectal cancer is probably caused by a complex interaction between many genetic and environmental factors over time. More and large studies with information on life style factors are required to assess these very possible gene-environment interactions. Identification of gene-environment interactions in cohorts with large relevant exposures has proven to be a useful approach.

Most environmental carcinogens require metabolic activation before they are able to form DNA damages. These activated forms may be detoxified or induce DNA repair or apoptosis. Thus, genetically determined susceptibility to colorectal cancer may depend on the balance among enzymes involved in metabolism and detoxification of carcinogens and on the balance between induction of DNA repair or apoptosis. Further investigations of the combined effects of polymorphisms between genes involved in these four mechanisms may help to clarify the influence of genetic variation in the carcinogenic process and may shed light on the complexities of the many pathways involved in colorectal cancer development, providing hypotheses for future functional studies.

\section{Conclusion}

In general, the studies suggest that the XPD Lys751Gln and XPD Asp312Asn polymorphisms may be associated with risk of colorectal adenomas with the possibility of interaction with smoking and alcohol consumption. The reported studies of polymorphisms in XPC and XPA in relation to risk of colorectal cancer are few, but the results are relatively consistent: In general, no association of the polymorphisms in the genes involved in NER $(X P D, X P C, X P A$ and ERCC1) was observed with risk of colorectal cancer. A possible interpretation of the results may be that the polymorphisms in the genes $X P D, X P C, X P A$ and ERCC1 are not of major importance in colorectal cancer carcinogenesis, which points towards that lowered repair capacity of the NER pathway may not be a risk factor for development of colorectal cancer.

The results were generally inconsistent or too few to compare to highlight any trend and no strong associations were observed for risk of colorectal adenomas or colorectal cancer. 
Overall, the role of genetic variants as SNPs in genes involved in NER is not satisfactorily clarified at present. It is possible that some of the SNPs may contribute to development of adenomas or colorectal cancer only in concomitance with certain dietary and life style factors. Furthermore, it may be only the joint effect of multiple polymorphisms that will provide us with information about genetic susceptibility for colorectal cancer. Larger carefully designed studies with stratified/adjusted analyses of gene-gene and geneenvironment interactions may be required in the future to achieve convincing statistically significant results on factors involved in colorectal carcinogenesis.

\section{Acknowledgement}

Our special thanks go to Anne Tjønneland and Kim Overvad for giving us the opportunity to study the polymorphisms in the Danish prospective cohort Diet, Cancer and Health. We thank Anne-Karin Jensen and Lourdes M. Pedersen for excellent technical assistance for the genotyping in our studies on the Danish cohort. And a thank goes to our co-authors of the manuscripts on the Danish studies for the valuable feedback when writing the manuscripts. The work of the present book chapter was supported by a research grant from the Danish Cancer Society (Grant number R2-A84-09-S2).

\section{References}

Andrew, A.S., Nelson, H.H., Kelsey, K.T., Moore, J.H., Meng, A.C., Casella, D.P., Tosteson, T.D., Schned, A.R. \& Karagas, M.R. (2006). Concordance of multiple analytical approaches demonstrates a complex relationship between DNA repair gene SNPs, smoking and bladder cancer susceptibility. Carcinogenesis, Vol. 27, No. 5, pp. (10301037)

Baccarelli, A., Calista, D., Minghetti, P., Marinelli, B., Albetti, B., Tseng, T., Hedayati, M., Grossman, L., Landi, G., Struewing, J.P. \& Landi, M.T. (2004). XPD gene polymorphism and host characteristics in the association with cutaneous malignant melanoma risk. Br.J.Cancer, Vol. 90, No. 2, pp. (497-502)

Balbi, J.C., Larrinaga, M.T., De Stefani, E., Mendilaharsu, M., Ronco, A.L., Boffetta, P. \& Brennan, P. (2001). Foods and risk of bladder cancer: a case-control study in Uruguay. Eur J Cancer Prev, Vol. 10, No. 5, pp. (453-458)

Batty, D., Rapic'-Otrin, V., Levine, A.S. \& Wood, R.D. (2000). Stable binding of human XPC complex to irradiated DNA confers strong discrimination for damaged sites. J.Mol.Biol., Vol. 300, No. 2, pp. (275-290)

Benhamou, S., Laplanche, A., Guillonneau, B., Mejean, A., Desgrandchamps, F., Schrameck, C., Degieux, V. \& Perin, F. (2003). DNA adducts in normal bladder tissue and bladder cancer risk. Mutagenesis, Vol. 18, No. 5, pp. (445-448)

Benhamou, S. \& Sarasin, A. (2005). ERCC2 /XPD gene polymorphisms and lung cancer: a HuGE review. Am.J.Epidemiol., Vol. 161, No. 1, pp. (1-14)

Berndt, S.I., Platz, E.A., Fallin, M.D., Thuita, L.W., Hoffman, S.C. \& Helzlsouer, K.J. (2006). Genetic variation in the nucleotide excision repair pathway and colorectal cancer risk. Cancer Epidemiol.Biomarkers Prev., Vol. 15, No. 11, pp. (2263-2269)

Bigler, J., Ulrich, C.M., Kawashima, T., Whitton, J. \& Potter, J.D. (2005). DNA repair polymorphisms and risk of colorectal adenomatous or hyperplastic polyps. Cancer Epidemiol.Biomarkers Prev., Vol. 14, No. 11 Pt 1, pp. (2501-2508) 
Bingham, S.A., Pignatelli, B., Pollock, J.R., Ellul, A., Malaveille, C., Gross, G., Runswick, S., Cummings, J.H. \& O'Neill, I.K. (1996). Does increased endogenous formation of Nnitroso compounds in the human colon explain the association between red meat and colon cancer? Carcinogenesis, Vol. 17, No. 3, pp. (515-523)

Binkova, B., Lewtas, J., Miskova, I., Lenicek, J. \& Sram, R. (1995). DNA adducts and personal air monitoring of carcinogenic polycyclic aromatic hydrocarbons in an environmentally exposed population. Carcinogenesis, Vol. 16, No. 5, pp. (1037-1046)

Blankenburg, S., Konig, I.R., Moessner, R., Laspe, P., Thoms, K.M., Krueger, U., Khan, S.G., Westphal, G., Berking, C., Volkenandt, M., Reich, K., Neumann, C., Ziegler, A., Kraemer, K.H. \& Emmert, S. (2005). Assessment of 3 xeroderma pigmentosum group $\mathrm{C}$ gene polymorphisms and risk of cutaneous melanoma: a case-control study. Carcinogenesis, Vol. 26, No. 6, pp. (1085-1090)

Brewster, A.M., Jorgensen, T.J., Ruczinski, I., Huang, H.Y., Hoffman, S., Thuita, L., Newschaffer, C., Lunn, R.M., Bell, D. \& Helzlsouer, K.J. (2006). Polymorphisms of the DNA repair genes XPD (Lys751Gln) and XRCC1 (Arg399Gln and Arg194Trp): relationship to breast cancer risk and familial predisposition to breast cancer. Breast Cancer Res.Treat., Vol. 95, No. 1, pp. (73-80)

Brooks, P.J. \& Theruvathu, J.A. (2005). DNA adducts from acetaldehyde: implications for alcohol-related carcinogenesis. Alcohol, Vol. 35, No. 3, pp. (187-193)

Bruemmer, B., White, E., Vaughan, T.L. \& Cheney, C.L. (1996). Nutrient intake in relation to bladder cancer among middle-aged men and women. Am J Epidemiol, Vol. 144, No. 5, pp. (485-495)

Burch, J.D., Craib, K.J., Choi, B.C., Miller, A.B., Risch, H.A. \& Howe, G.R. (1987). An exploratory case-control study of brain tumors in adults. J.Natl.Cancer Inst., Vol. 78, No. 4, pp. (601-609)

Carozza, S.E., Olshan, A.F., Faustman, E.M., Gula, M.J., Kolonel, L.N., Austin, D.F., West, E.D., Weiss, N.S., Swanson, G.M., Lyon, J.L. \& . (1995). Maternal exposure to Nnitrosatable drugs as a risk factor for childhood brain tumours. Int.J.Epidemiol., Vol. 24, No. 2, pp. (308-312)

Cleaver, J.E. (2005). Cancer in xeroderma pigmentosum and related disorders of DNA repair. Nat.Rev.Cancer, Vol. 5, No. 7, pp. (564-573)

Correa Lima, M.P. \& Gomes-da-Silva, M.H. (2005). Colorectal cancer: lifestyle and dietary factors. Nutr.Hosp., Vol. 20, No. 4, pp. (235-241)

Costa, S., Pinto, D., Pereira, D., Rodrigues, H., Cameselle-Teijeiro, J., Medeiros, R. \& Schmitt, F. (2007). DNA repair polymorphisms might contribute differentially on familial and sporadic breast cancer susceptibility: a study on a Portuguese population. Breast Cancer Res.Treat., Vol. 103, No. 2, pp. (209-217)

Coverley, D., Kenny, M.K., Lane, D.P. \& Wood, R.D. (1992). A role for the human singlestranded DNA binding protein HSSB/RPA in an early stage of nucleotide excision repair. Nucleic Acids Res., Vol. 20, No. 15, pp. (3873-3880)

Cross, A.J., Pollock, J.R. \& Bingham, S.A. (2003). Haem, not protein or inorganic iron, is responsible for endogenous intestinal $\mathrm{N}$-nitrosation arising from red meat. Cancer Res., Vol. 63, No. 10, pp. (2358-2360)

Culp, S.J., Gaylor, D.W., Sheldon, W.G., Goldstein, L.S. \& Beland, F.A. (1998). A comparison of the tumors induced by coal tar and benzo[a]pyrene in a 2-year bioassay. Carcinogenesis, Vol. 19, No. 1, pp. (117-124) 
de Laat, W.L., Sijbers, A.M., Odijk, H., Jaspers, N.G. \& Hoeijmakers, J.H. (1998). Mapping of interaction domains between human repair proteins ERCC1 and XPF. Nucleic Acids Res., Vol. 26, No. 18, pp. (4146-4152)

De, R.K., Szaumkessel, M., De, R., I, Dehoorne, A., Vral, A., Claes, K., Velghe, A., Van, M.J. \& Thierens, H. (2007). Polymorphisms in base-excision repair and nucleotideexcision repair genes in relation to lung cancer risk. Mutat.Res., Vol. 631, No. 2, pp. (101-110)

Debniak, T., Scott, R.J., Huzarski, T., Byrski, T., Masojc, B., van de, W.T., Serrano-Fernandez, P., Gorski, B., Cybulski, C., Gronwald, J., Debniak, B., Maleszka, R., Kladny, J., Bieniek, A., Nagay, L., Haus, O., Grzybowska, E., Wandzel, P., Niepsuj, S., Narod, S.A. \& Lubinski, J. (2006). XPD common variants and their association with melanoma and breast cancer risk. Breast Cancer Res.Treat., Vol. 98, No. 2, pp. (209215)

Dingley, K.H., Ubick, E.A., Chiarappa-Zucca, M.L., Nowell, S., Abel, S., Ebeler, S.E., Mitchell, A.E., Burns, S.A., Steinberg, F.M. \& Clifford, A.J. (2003). Effect of dietary constituents with chemopreventive potential on adduct formation of a low dose of the heterocyclic amines PhIP and IQ and phase II hepatic enzymes. Nutr.Cancer, Vol. 46, No. 2, pp. (212-221)

Doyle, V.C. (2007). Nutrition and colorectal cancer risk: a literature review. Gastroenterol.Nurs., Vol. 30, No. 3, pp. (178-182)

Drapkin, R., Reardon, J.T., Ansari, A., Huang, J.C., Zawel, L., Ahn, K., Sancar, A. \& Reinberg, D. (1994). Dual role of TFIIH in DNA excision repair and in transcription by RNA polymerase II. Nature, Vol. 368, No. 6473, pp. (769-772)

Dufloth, R.M., Costa, S., Schmitt, F. \& Zeferino, L.C. (2005). DNA repair gene polymorphisms and susceptibility to familial breast cancer in a group of patients from Campinas, Brazil. Genet.Mol.Res., Vol. 4, No. 4, pp. (771-782)

Engin, A.B., Karahalil, B., Engin, A. \& Karakaya, A.E. (2010). Oxidative stress, Helicobacter pylori, and OGG1 Ser326Cys, XPC Lys939Gln, and XPD Lys751Gln polymorphisms in a Turkish population with colorectal carcinoma. Genet.Test.Mol.Biomarkers, Vol. 14, No. 4, pp. (559-564)

Evans, E., Fellows, J., Coffer, A. \& Wood, R.D. (1997). Open complex formation around a lesion during nucleotide excision repair provides a structure for cleavage by human XPG protein. EMBO J., Vol. 16, No. 3, pp. (625-638)

Fang, J.L. \& Vaca, C.E. (1997). Detection of DNA adducts of acetaldehyde in peripheral white blood cells of alcohol abusers. Carcinogenesis, Vol. 18, No. 4, pp. (627-632)

Feaver, W.J., Svejstrup, J.Q., Bardwell, L., Bardwell, A.J., Buratowski, S., Gulyas, K.D., Donahue, T.F., Friedberg, E.C. \& Kornberg, R.D. (1993). Dual roles of a multiprotein complex from S. cerevisiae in transcription and DNA repair. Cell, Vol. 75, No. 7, pp. (1379-1387)

Festa, F., Kumar, R., Sanyal, S., Unden, B., Nordfors, L., Lindholm, B., Snellman, E., Schalling, M., Forsti, A. \& Hemminki, K. (2005). Basal cell carcinoma and variants in genes coding for immune response, DNA repair, folate and iron metabolism. Mutat.Res., Vol. 574, No. 1-2, pp. (105-111)

Forsti, A., Angelini, S., Festa, F., Sanyal, S., Zhang, Z., Grzybowska, E., Pamula, J., Pekala, W., Zientek, H., Hemminki, K. \& Kumar, R. (2004). Single nucleotide polymorphisms in breast cancer. Oncol.Rep., Vol. 11, No. 4, pp. (917-922) 
Georgiadis, P., Topinka, J., Stoikidou, M., Kaila, S., Gioka, M., Katsouyanni, K., Sram, R., Autrup, H. \& Kyrtopoulos, S.A. (2001). Biomarkers of genotoxicity of air pollution (the AULIS project): bulky DNA adducts in subjects with moderate to low exposures to airborne polycyclic aromatic hydrocarbons and their relationship to environmental tobacco smoke and other parameters. Carcinogenesis, Vol. 22, No. 9, pp. (1447-1457)

Goldberg, M.S., Parent, M.E., Siemiatycki, J., Desy, M., Nadon, L., Richardson, L., Lakhani, R., Latreille, B. \& Valois, M.F. (2001). A case-control study of the relationship between the risk of colon cancer in men and exposures to occupational agents. Am J Ind Med, Vol. 39, No. 6, pp. (531-546)

Gomaa, E.A., Gray, J.I., Rabie, S., Lopez-Bote, C. \& Booren, A.M. (1993). Polycyclic aromatic hydrocarbons in smoked food products and commercial liquid smoke flavourings. Food Addit.Contam, Vol. 10, No. 5, pp. (503-521)

Goodman, J.E., Mechanic, L.E., Luke, B.T., Ambs, S., Chanock, S. \& Harris, C.C. (2006). Exploring SNP-SNP interactions and colon cancer risk using polymorphism interaction analysis. Int.J.Cancer, Vol. 118, No. 7, pp. (1790-1797)

Guillen, M.D., Sopelana, P. \& Partearroyo, M.A. (1997). Food as a source of polycyclic aromatic carcinogens. Rev.Environ.Health, Vol. 12, No. 3, pp. (133-146)

Guzder, S.N., Sung, P., Prakash, L. \& Prakash, S. (1998). Affinity of yeast nucleotide excision repair factor 2, consisting of the Rad4 and Rad23 proteins, for ultraviolet damaged DNA. J.Biol.Chem., Vol. 273, No. 47, pp. (31541-31546)

Han, J., Colditz, G.A., Liu, J.S. \& Hunter, D.J. (2005). Genetic variation in XPD, sun exposure, and risk of skin cancer. Cancer Epidemiol.Biomarkers Prev., Vol. 14, No. 6, pp. (15391544)

Hanawalt, P.C. (2002). Subpathways of nucleotide excision repair and their regulation. Oncogene, Vol. 21, No. 58, pp. (8949-8956)

Hansen, R.D., Sorensen, M., Tjonneland, A., Overvad, K., Wallin, H., Raaschou-Nielsen, O. \& Vogel, U. (2007). XPA A23G, XPC Lys939Gln, XPD Lys751Gln and XPD Asp312Asn polymorphisms, interactions with smoking, alcohol and dietary factors, and risk of colorectal cancer. Mutat.Res., Vol. 619, No. 1-2, pp. (68-80)

Hansen, R.D., Sorensen, M., Tjonneland, A., Overvad, K., Wallin, H., Raaschou-Nielsen, O. \& Vogel, U. (2008). A haplotype of polymorphisms in ASE-1, RAI and ERCC1 and the effects of tobacco smoking and alcohol consumption on risk of colorectal cancer: a Danish prospective case-cohort study. BMC.Cancer, Vol. 8, pp. (54)

Hecht, S.S. (2003). Tobacco carcinogens, their biomarkers and tobacco-induced cancer. Nat.Rev.Cancer, Vol. 3, No. 10, pp. (733-744)

Hecht, S.S. \& Hoffmann, D. (1988). Tobacco-specific nitrosamines, an important group of carcinogens in tobacco and tobacco smoke. Carcinogenesis, Vol. 9, No. 6, pp. (875884)

Hemminki, K., Dickey, C., Karlsson, S., Bell, D., Hsu, Y., Tsai, W.Y., Mooney, L.A., Savela, K. \& Perera, F.P. (1997). Aromatic DNA adducts in foundry workers in relation to exposure, life style and CYP1A1 and glutathione transferase M1 genotype. Carcinogenesis, Vol. 18, No. 2, pp. (345-350)

Hemminki, K., Grzybowska, E., Chorazy, M., Twardowska-Saucha, K., Sroczynski, J.W., Putman, K.L., Randerath, K., Phillips, D.H., Hewer, A., Santella, R.M. \& . (1990a). 
DNA adducts in human environmentally exposed to aromatic compounds in an industrial area of Poland. Carcinogenesis, Vol. 11, No. 7, pp. (1229-1231)

Hemminki, K., Randerath, K., Reddy, M.V., Putman, K.L., Santella, R.M., Perera, F.P., Young, T.L., Phillips, D.H., Hewer, A. \& Savela, K. (1990b). Postlabeling and immunoassay analysis of polycyclic aromatic hydrocarbons--adducts of deoxyribonucleic acid in white blood cells of foundry workers. Scand J Work Environ Health, Vol. 16, No. 3, pp. (158-162)

Hemminki, K., Soderling, J., Ericson, P., Norbeck, H.E. \& Segerback, D. (1994). DNA adducts among personnel servicing and loading diesel vehicles. Carcinogenesis, Vol. 15, No. 4, pp. (767-769)

Hotchkiss, J.H. (1989). Preformed N-nitroso compounds in foods and beverages. Cancer Surv., Vol. 8, No. 2, pp. (295-321)

Hou, S.M., Falt, S., Angelini, S., Yang, K., Nyberg, F., Lambert, B. \& Hemminki, K. (2002). The XPD variant alleles are associated with increased aromatic DNA adduct level and lung cancer risk. Carcinogenesis, Vol. 23, No. 4, pp. (599-603)

$\mathrm{Hu}, \mathrm{Z}$., Wei, Q., Wang, X. \& Shen, H. (2004). DNA repair gene XPD polymorphism and lung cancer risk: a meta-analysis. Lung Cancer, Vol. 46, No. 1, pp. (1-10)

Hu, Z., Xu, L., Shao, M., Yuan, J., Wang, Y., Wang, F., Yuan, W., Qian, J., Ma, H., Wang, Y., Liu, H., Chen, W., Yang, L., Jing, G., Huo, X., Chen, F., Jin, L., Wei, Q., Wu, T., Lu, D., Huang, W. \& Shen, H. (2006). Polymorphisms in the two helicases ERCC2/XPD and ERCC3/XPB of the transcription factor IIH complex and risk of lung cancer: a case-control analysis in a Chinese population. Cancer Epidemiol.Biomarkers Prev., Vol. 15, No. 7, pp. (1336-1340)

Huang, W.Y., Berndt, S.I., Kang, D., Chatterjee, N., Chanock, S.J., Yeager, M., Welch, R., Bresalier, R.S., Weissfeld, J.L. \& Hayes, R.B. (2006). Nucleotide excision repair gene polymorphisms and risk of advanced colorectal adenoma: XPC polymorphisms modify smoking-related risk. Cancer Epidemiol.Biomarkers Prev., Vol. 15, No. 2, pp. (306-311)

Huang, W.Y., Chow, W.H., Rothman, N., Lissowska, J., Llaca, V., Yeager, M., Zatonski, W. \& Hayes, R.B. (2005). Selected DNA repair polymorphisms and gastric cancer in Poland. Carcinogenesis, Vol. 26, No. 8, pp. (1354-1359)

Hunting, D.J., Gowans, B.J. \& Dresler, S.L. (1991). DNA polymerase delta mediates excision repair in growing cells damaged with ultraviolet radiation. Biochem.Cell Biol., Vol. 69, No. 4, pp. (303-308)

International Agency for Research on Cancer (IARC). Polynuclear aromatic compounds. Part I: Chemical, environmental and experimental data. IARC monograph on the evaluation of carcinogenic risk of chemical to man. (32). 1983. Lyon, France, IARC.

International Agency for Research on Cancer (IARC) (2003). Fruit and vegetables IARC Press, Lyon

Iversen, L.H., Pedersen, L., Riis, A., Friis, S., Laurberg, S. \& Sorensen, H.T. (2005). Population-based study of short- and long-term survival from colorectal cancer in Denmark, 1977-1999. Br.J.Surg., Vol. 92, No. 7, pp. (873-880)

Jaspers, N.G., Raams, A., Silengo, M.C., Wijgers, N., Niedernhofer, L.J., Robinson, A.R., Giglia-Mari, G., Hoogstraten, D., Kleijer, W.J., Hoeijmakers, J.H. \& Vermeulen, W. (2007). First reported patient with human ERCC1 deficiency has cerebro-oculo- 
facio-skeletal syndrome with a mild defect in nucleotide excision repair and severe developmental failure. Am.J.Hum.Genet., Vol. 80, No. 3, pp. (457-466)

Jemal, A., Siegel, R., Ward, E., Murray, T., Xu, J., Smigal, C. \& Thun, M.J. (2006). Cancer statistics, 2006. CA Cancer J.Clin., Vol. 56, No. 2, pp. (106-130)

Ji, B.T., Weissfeld, J.L., Chow, W.H., Huang, W.Y., Schoen, R.E. \& Hayes, R.B. (2006). Tobacco smoking and colorectal hyperplastic and adenomatous polyps. Cancer Epidemiol.Biomarkers Prev., Vol. 15, No. 5, pp. (897-901)

Jo, H., Kang, S., Kim, S.I., Kim, J.W., Park, N.H., Song, Y.S., Park, S.Y., Kang, S.B. \& Lee, H.P. (2007). The C19007T Polymorphism of ERCC1 and Its Correlation with the Risk of Epithelial Ovarian and Endometrial Cancer in Korean Women. A Case Control Study. Gynecol.Obstet.Invest, Vol. 64, No. 2, pp. (84-88)

Johnson, I.T. \& Lund, E.K. (2007). Review article: nutrition, obesity and colorectal cancer. Aliment.Pharmacol.Ther., Vol. 26, No. 2, pp. (161-181)

Jorgensen, T.J., Visvanathan, K., Ruczinski, I., Thuita, L., Hoffman, S. \& Helzlsouer, K.J. (2007). Breast cancer risk is not associated with polymorphic forms of xeroderma pigmentosum genes in a cohort of women from Washington County, Maryland. Breast Cancer Res.Treat., Vol. 101, No. 1, pp. (65-71)

Joshi, A.D., Corral, R., Siegmund, K.D., Haile, R.W., Le, M.L., Martinez, M.E., Ahnen, D.J., Sandler, R.S., Lance, P. \& Stern, M.C. (2009). Red meat and poultry intake, polymorphisms in the nucleotide excision repair and mismatch repair pathways and colorectal cancer risk. Carcinogenesis, Vol. 30, No. 3, pp. (472-479)

Justenhoven, C., Hamann, U., Pesch, B., Harth, V., Rabstein, S., Baisch, C., Vollmert, C., Illig, T., Ko, Y.D., Bruning, T. \& Brauch, H. (2004). ERCC2 genotypes and a corresponding haplotype are linked with breast cancer risk in a German population. Cancer Epidemiol.Biomarkers Prev., Vol. 13, No. 12, pp. (2059-2064)

Khan, S.G., Metter, E.J., Tarone, R.E., Bohr, V.A., Grossman, L., Hedayati, M., Bale, S.J., Emmert, S. \& Kraemer, K.H. (2000). A new xeroderma pigmentosum group C poly(AT) insertion/deletion polymorphism. Carcinogenesis, Vol. 21, No. 10, pp. (1821-1825)

Kiyohara, C. \& Yoshimasu, K. (2007). Genetic polymorphisms in the nucleotide excision repair pathway and lung cancer risk: a meta-analysis. Int.J.Med.Sci., Vol. 4, No. 2, pp. (59-71)

Kobayashi, K., Karran, P., Oda, S. \& Yanaga, K. (2005). Involvement of mismatch repair in transcription-coupled nucleotide excision repair. Hum.Cell, Vol. 18, No. 3, pp. (103115)

Kyrtopoulos, S.A., Georgiadis, P., Autrup, H., Demopoulos, N.A., Farmer, P., Haugen, A., Katsouyanni, K., Lambert, B., Ovrebo, S., Sram, R., Stephanou, G. \& Topinka, J. (2001). Biomarkers of genotoxicity of urban air pollution. Overview and descriptive data from a molecular epidemiology study on populations exposed to moderate-tolow levels of polycyclic aromatic hydrocarbons: the AULIS project. Mutat Res, Vol. 496, No. 1-2, pp. (207-228)

Laska, M.J., Nexo, B.A., Vistisen, K., Poulsen, H.E., Loft, S. \& Vogel, U. (2005). Polymorphisms in RAI and in genes of nucleotide and base excision repair are not associated with risk of testicular cancer. Cancer Lett., Vol. 225, No. 2, pp. (245-251)

Lee, K.M., Choi, J.Y., Kang, C., Kang, C.P., Park, S.K., Cho, H., Cho, D.Y., Yoo, K.Y., Noh, D.Y., Ahn, S.H., Park, C.G., Wei, Q. \& Kang, D. (2005). Genetic polymorphisms of 
selected DNA repair genes, estrogen and progesterone receptor status, and breast cancer risk. Clin.Cancer Res., Vol. 11, No. 12, pp. (4620-4626)

Lewin, M.H., Bailey, N., Bandaletova, T., Bowman, R., Cross, A.J., Pollock, J., Shuker, D.E. \& Bingham, S.A. (2006). Red meat enhances the colonic formation of the DNA adduct O6-carboxymethyl guanine: implications for colorectal cancer risk. Cancer Res., Vol. 66, No. 3, pp. (1859-1865)

Lewtas, J., Walsh, D., Williams, R. \& Dobias, L. (1997). Air pollution exposure-DNA adduct dosimetry in humans and rodents: evidence for non-linearity at high doses. Mutat Res, Vol. 378, No. 1-2, pp. (51-63)

Li, C., Hu, Z., Liu, Z., Wang, L.E., Strom, S.S., Gershenwald, J.E., Lee, J.E., Ross, M.I., Mansfield, P.F., Cormier, J.N., Prieto, V.G., Duvic, M., Grimm, E.A. \& Wei, Q. (2006a). Polymorphisms in the DNA repair genes XPC, XPD, and XPG and risk of cutaneous melanoma: a case-control analysis. Cancer Epidemiol.Biomarkers Prev., Vol. 15, No. 12, pp. (2526-2532)

Li, H., Yao, L., Ouyang, T., Li, J., Wang, T., Fan, Z., Fan, T., Dong, B., Lin, B., Li, J. \& Xie, Y. (2006b). Association of p73 G4C14-to-A4T14 (GC/AT) polymorphism with breast cancer survival. Carcinogenesis,

Lovatt, T., Alldersea, J., Lear, J.T., Hoban, P.R., Ramachandran, S., Fryer, A.A., Smith, A.G. \& Strange, R.C. (2005). Polymorphism in the nuclear excision repair gene ERCC2/XPD: association between an exon 6-exon 10 haplotype and susceptibility to cutaneous basal cell carcinoma. Hum.Mutat., Vol. 25, No. 4, pp. (353-359)

Masutani, C., Sugasawa, K., Yanagisawa, J., Sonoyama, T., Ui, M., Enomoto, T., Takio, K., Tanaka, K., van der Spek, P.J., Bootsma, D. \& . (1994). Purification and cloning of a nucleotide excision repair complex involving the xeroderma pigmentosum group $\mathrm{C}$ protein and a human homologue of yeast RAD23. EMBO J., Vol. 13, No. 8, pp. (1831-1843)

Matullo, G., Palli, D., Peluso, M., Guarrera, S., Carturan, S., Celentano, E., Krogh, V., Munnia, A., Tumino, R., Polidoro, S., Piazza, A. \& Vineis, P. (2001). XRCC1, XRCC3, XPD gene polymorphisms, smoking and (32)P-DNA adducts in a sample of healthy subjects. Carcinogenesis, Vol. 22, No. 9, pp. (1437-1445)

Meador, J.P., Stein, J.E., Reichert, W.L. \& Varanasi, U. (1995). Bioaccumulation of polycyclic aromatic hydrocarbons by marine organisms. Rev.Environ.Contam Toxicol., Vol. 143, pp. (79-165)

Mechanic, L.E., Millikan, R.C., Player, J., de Cotret, A.R., Winkel, S., Worley, K., Heard, K., Heard, K., Tse, C.K. \& Keku, T. (2006). Polymorphisms in nucleotide excision repair genes, smoking and breast cancer in African Americans and whites: a populationbased case-control study. Carcinogenesis, Vol. 27, No. 7, pp. (1377-1385)

Melikian, A.A., Sun, P., Prokopczyk, B., El-Bayoumy, K., Hoffmann, D., Wang, X. \& Waggoner, S. (1999). Identification of benzo[a]pyrene metabolites in cervical mucus and DNA adducts in cervical tissues in humans by gas chromatographymass spectrometry. Cancer Lett, Vol. 146, pp. (127-134)

Metsola, K., Kataja, V., Sillanpaa, P., Siivola, P., Heikinheimo, L., Eskelinen, M., Kosma, V.M., Uusitupa, M. \& Hirvonen, A. (2005). XRCC1 and XPD genetic polymorphisms, smoking and breast cancer risk in a Finnish case-control study. Breast Cancer Res., Vol. 7, No. 6, pp. (R987-R997) 
Miller, K.L., Karagas, M.R., Kraft, P., Hunter, D.J., Catalano, P.J., Byler, S.H. \& Nelson, H.H. (2006). XPA, haplotypes, and risk of basal and squamous cell carcinoma. Carcinogenesis, Vol. 27, No. 8, pp. (1670-1675)

Millikan, R.C., Hummer, A., Begg, C., Player, J., de Cotret, A.R., Winkel, S., Mohrenweiser, H., Thomas, N., Armstrong, B., Kricker, A., Marrett, L.D., Gruber, S.B., Culver, H.A., Zanetti, R., Gallagher, R.P., Dwyer, T., Rebbeck, T.R., Busam, K., From, L., Mujumdar, U. \& Berwick, M. (2006). Polymorphisms in nucleotide excision repair genes and risk of multiple primary melanoma: the Genes Environment and Melanoma Study. Carcinogenesis, Vol. 27, No. 3, pp. (610-618)

Mirvish, S.S. (1995). Role of N-nitroso compounds (NOC) and N-nitrosation in etiology of gastric, esophageal, nasopharyngeal and bladder cancer and contribution to cancer of known exposures to NOC. Cancer Lett., Vol. 93, No. 1, pp. (17-48)

Moller, P., Wallin, H., Vogel, U., Autrup, H., Risom, L., Hald, M.T., Daneshvar, B., Dragsted, L.O., Poulsen, H.E. \& Loft, S. (2002). Mutagenicity of 2-amino-3-methylimidazo[4,5f]quinoline in colon and liver of Big Blue rats: role of DNA adducts, strand breaks, DNA repair and oxidative stress. Carcinogenesis, Vol. 23, No. 8, pp. (1379-1385)

Mooney, L.A., Bell, D.A., Santella, R.M., Van Bennekum, A.M., Ottman, R., Paik, M., Blaner, W.S., Lucier, G.W., Covey, L., Young, T.L., Cooper, T.B., Glassman, A.H. \& Perera, F.P. (1997). Contribution of genetic and nutritional factors to DNA damage in heavy smokers. Carcinogenesis, Vol. 18, No. 3, pp. (503-509)

Mooney, L.A., Madsen, A.M., Tang, D., Orjuela, M.A., Tsai, W.Y., Garduno, E.R. \& Perera, F.P. (2005). Antioxidant vitamin supplementation reduces benzo(a)pyrene-DNA adducts and potential cancer risk in female smokers. Cancer Epidemiol Biomarkers Prev, Vol. 14, No. 1, pp. (237-242)

Moreno, V., Gemignani, F., Landi, S., Gioia-Patricola, L., Chabrier, A., Blanco, I., Gonzalez, S., Guino, E., Capella, G. \& Canzian, F. (2006). Polymorphisms in genes of nucleotide and base excision repair: risk and prognosis of colorectal cancer. Clin.Cancer Res., Vol. 12, No. 7 Pt 1, pp. (2101-2108)

Mort, R., Mo, L., McEwan, C. \& Melton, D.W. (2003). Lack of involvement of nucleotide excision repair gene polymorphisms in colorectal cancer. Br J Cancer, Vol. 89, No. 2, pp. (333-337)

$\mathrm{Mu}$, D., Hsu, D.S. \& Sancar, A. (1996). Reaction mechanism of human DNA repair excision nuclease. J.Biol.Chem., Vol. 271, No. 14, pp. (8285-8294)

Nelson, H.H., Christensen, B. \& Karagas, M.R. (2005). The XPC poly-AT polymorphism in non-melanoma skin cancer. Cancer Lett., Vol. 222, No. 2, pp. (205-209)

Niedernhofer, L.J., Essers, J., Weeda, G., Beverloo, B., de, W.J., Muijtjens, M., Odijk, H., Hoeijmakers, J.H. \& Kanaar, R. (2001). The structure-specific endonuclease Ercc1$\mathrm{Xpf}$ is required for targeted gene replacement in embryonic stem cells. EMBO J., Vol. 20, No. 22, pp. (6540-6549)

Nielsen, P.S., Andreassen, A., Farmer, P.B., Ovrebo, S. \& Autrup, H. (1996a). Biomonitoring of diesel exhaust-exposed workers. DNA and hemoglobin adducts and urinary 1hydroxypyrene as markers of exposure. Toxicol Lett, Vol. 86, No. 1, pp. (27-37)

Nielsen, P.S., de Pater, N., Okkels, H. \& Autrup, H. (1996b). Environmental air pollution and DNA adducts in Copenhagen bus drivers--effect of GSTM1 and NAT2 genotypes on adduct levels. Carcinogenesis, Vol. 17, No. 5, pp. (1021-1027) 
Nielsen, P.S., Okkels, H., Sigsgaard, T., Kyrtopoulos, S. \& Autrup, H. (1996c). Exposure to urban and rural air pollution: DNA and protein adducts and effect of glutathioneS-transferase genotype on adduct levels. Int Arch Occup Environ Health, Vol. 68, No. 3, pp. (170-176)

Norat, T., Bingham, S., Ferrari, P., Slimani, N., Jenab, M., Mazuir, M., Overvad, K., Olsen, A., Tjonneland, A., Clavel, F., Boutron-Ruault, M.C., Kesse, E., Boeing, H., Bergmann, M.M., Nieters, A., Linseisen, J., Trichopoulou, A., Trichopoulos, D., Tountas, Y., Berrino, F., Palli, D., Panico, S., Tumino, R., Vineis, P., Bueno-de-Mesquita, H.B., Peeters, P.H., Engeset, D., Lund, E., Skeie, G., Ardanaz, E., Gonzalez, C., Navarro, C., Quiros, J.R., Sanchez, M.J., Berglund, G., Mattisson, I., Hallmans, G., Palmqvist, R., Day, N.E., Khaw, K.T., Key, T.J., San Joaquin, M., Hemon, B., Saracci, R., Kaaks, R. \& Riboli, E. (2005). Meat, fish, and colorectal cancer risk: the European Prospective Investigation into cancer and nutrition. J.Natl.Cancer Inst., Vol. 97, No. 12, pp. (906-916)

Palli, D., Masala, G., Peluso, M., Gaspari, L., Krogh, V., Munnia, A., Panico, S., Saieva, C., Tumino, R., Vineis, P. \& Garte, S. (2004). The effects of diet on DNA bulky adduct levels are strongly modified by GSTM1 genotype: a study on 634 subjects. Carcinogenesis, Vol. 25, No. 4, pp. (577-584)

Palli, D., Masala, G., Vineis, P., Garte, S., Saieva, C., Krogh, V., Panico, S., Tumino, R., Munnia, A., Riboli, E. \& Peluso, M. (2003). Biomarkers of dietary intake of micronutrients modulate DNA adduct levels in healthy adults. Carcinogenesis, Vol. 24, No. 4, pp. (739-746)

Palli, D., Russo, A., Masala, G., Saieva, C., Guarrera, S., Carturan, S., Munnia, A., Matullo, G. \& Peluso, M. (2001). DNA adduct levels and DNA repair polymorphisms in trafficexposed workers and a general population sample. Int J Cancer, Vol. 94, No. 1, pp. (121-127)

Palli, D., Vineis, P., Russo, A., Berrino, F., Krogh, V., Masala, G., Munnia, A., Panico, S., Taioli, E., Tumino, R., Garte, S. \& Peluso, M. (2000). Diet, metabolic polymorphisms and dna adducts: the EPIC-Italy cross-sectional study. Int J Cancer, Vol. 87, No. 3, pp. (444-451)

Park, C.H., Mu, D., Reardon, J.T. \& Sancar, A. (1995). The general transcription-repair factor TFIIH is recruited to the excision repair complex by the XPA protein independent of the TFIIE transcription factor. J.Biol.Chem., Vol. 270, No. 9, pp. (4896-4902)

Park, C.H. \& Sancar, A. (1994). Formation of a ternary complex by human XPA, ERCC1, and ERCC4(XPF) excision repair proteins. Proc.Natl.Acad.Sci.U.S.A, Vol. 91, No. 11, pp. (5017-5021)

Park, J.Y., Park, S.H., Choi, J.E., Lee, S.Y., Jeon, H.S., Cha, S.I., Kim, C.H., Park, J.H., Kam, S., Park, R.W., Kim, I.S. \& Jung, T.H. (2002). Polymorphisms of the DNA repair gene xeroderma pigmentosum group A and risk of primary lung cancer. Cancer Epidemiol.Biomarkers Prev., Vol. 11, No. 10 Pt 1, pp. (993-997)

Peluso, M., Merlo, F., Munnia, A., Valerio, F., Perrotta, A., Puntoni, R. \& Parodi, S. (1998). 32P-postlabeling detection of aromatic adducts in the white blood cell DNA of nonsmoking police officers. Cancer Epidemiol Biomarkers Prev, Vol. 7, No. 1, pp. (311)

Perera, F.P., Dickey, C., Santella, R., O'Neill, J.P., Albertini, R.J., Ottman, R., Tsai, W.Y., Mooney, L.A., Savela, K. \& Hemminki, K. (1994). Carcinogen-DNA adducts and 
gene mutation in foundry workers with low-level exposure to polycyclic aromatic hydrocarbons. Carcinogenesis, Vol. 15, No. 12, pp. (2905-2910)

Perera, F.P., Hemminki, K., Young, T.L., Brenner, D., Kelly, G. \& Santella, R.M. (1988). Detection of polycyclic aromatic hydrocarbon-DNA adducts in white blood cells of foundry workers. Cancer Res, Vol. 48, No. 8, pp. (2288-2291)

Peters, U., Sinha, R., Bell, D.A., Rothman, N., Grant, D.J., Watson, M.A., Kulldorff, M., Brooks, L.R., Warren, S.H. \& DeMarini, D.M. (2004). Urinary mutagenesis and fried red meat intake: influence of cooking temperature, phenotype, and genotype of metabolizing enzymes in a controlled feeding study. Environ Mol Mutagen, Vol. 43, No. 1, pp. (53-74)

Phillips, D.H. (2002). Smoking-related DNA and protein adducts in human tissues. Carcinogenesis, Vol. 23, No. 12, pp. (1979-2004)

Pierre, F., Tache, S., Petit, C.R., Van der, M.R. \& Corpet, D.E. (2003). Meat and cancer: haemoglobin and haemin in a low-calcium diet promote colorectal carcinogenesis at the aberrant crypt stage in rats. Carcinogenesis, Vol. 24, No. 10, pp. (1683-1690)

Poirier, M.C., Weston, A., Schoket, B., Shamkhani, H., Pan, C.F., McDiarmid, M.A., Scott, B.G., Deeter, D.P., Heller, J.M., Jacobson-Kram, D. \& Rothman, N. (1998). Biomonitoring of United States Army soldiers serving in Kuwait in 1991. Cancer Epidemiol Biomarkers Prev, Vol. 7, No. 6, pp. (545-551)

Popanda, O., Schattenberg, T., Phong, C.T., Butkiewicz, D., Risch, A., Edler, L., Kayser, K., Dienemann, H., Schulz, V., Drings, P., Bartsch, H. \& Schmezer, P. (2004). Specific combinations of DNA repair gene variants and increased risk for non-small cell lung cancer. Carcinogenesis, Vol. 25, No. 12, pp. (2433-2441)

Preston-Martin, S. \& Mack, W. (1991). Gliomas and meningiomas in men in Los Angeles County: investigation of exposures to N-nitroso compounds. IARC Sci.Publ., No. 105, pp. (197-203)

Qiao, Y., Spitz, M.R., Shen, H., Guo, Z., Shete, S., Hedayati, M., Grossman, L., Mohrenweiser, H. \& Wei, Q. (2002). Modulation of repair of ultraviolet damage in the host-cell reactivation assay by polymorphic XPC and XPD/ERCC2 genotypes. Carcinogenesis, Vol. 23, No. 2, pp. (295-299)

Reardon, J.T., Mu, D. \& Sancar, A. (1996). Overproduction, purification, and characterization of the XPC subunit of the human DNA repair excision nuclease. J.Biol.Chem., Vol. 271, No. 32, pp. (19451-19456)

Reardon, J.T. \& Sancar, A. (2002). Molecular anatomy of the human excision nuclease assembled at sites of DNA damage. Mol.Cell Biol., Vol. 22, No. 16, pp. (5938-5945)

Ritchey, J.D., Huang, W.Y., Chokkalingam, A.P., Gao, Y.T., Deng, J., Levine, P., Stanczyk, F.Z. \& Hsing, A.W. (2005). Genetic variants of DNA repair genes and prostate cancer: a population-based study. Cancer Epidemiol.Biomarkers Prev., Vol. 14, No. 7, pp. (1703-1709)

Rothman, N., Correa-Villasenor, A., Ford, D.P., Poirier, M.C., Haas, R., Hansen, J.A., O'Toole, T. \& Strickland, P.T. (1993). Contribution of occupation and diet to white blood cell polycyclic aromatic hydrocarbon-DNA adducts in wildland firefighters. Cancer Epidemiol Biomarkers Prev, Vol. 2, No. 4, pp. (341-347)

Rothman, N., Poirier, M.C., Baser, M.E., Hansen, J.A., Gentile, C., Bowman, E.D. \& Strickland, P.T. (1990). Formation of polycyclic aromatic hydrocarbon-DNA 
adducts in peripheral white blood cells during consumption of charcoal-broiled beef. Carcinogenesis, Vol. 11, No. 7, pp. (1241-1243)

Sanyal, S., Festa, F., Sakano, S., Zhang, Z., Steineck, G., Norming, U., Wijkstrom, H., Larsson, P., Kumar, R. \& Hemminki, K. (2004). Polymorphisms in DNA repair and metabolic genes in bladder cancer. Carcinogenesis, Vol. 25, No. 5, pp. (729-734)

Schabath, M.B., Delclos, G.L., Grossman, H.B., Wang, Y., Lerner, S.P., Chamberlain, R.M., Spitz, M.R. \& Wu, X. (2005). Polymorphisms in XPD exons 10 and 23 and bladder cancer risk. Cancer Epidemiol.Biomarkers Prev., Vol. 14, No. 4, pp. (878-884)

Schaeffer, L., Roy, R., Humbert, S., Moncollin, V., Vermeulen, W., Hoeijmakers, J.H., Chambon, P. \& Egly, J.M. (1993). DNA repair helicase: a component of BTF2 (TFIIH) basic transcription factor. Science, Vol. 260, No. 5104, pp. (58-63)

Schottenfeld, D. \& Winawer, S.J. (1996). Cancers of the large intestine, In: Cancer Epidemiology and Prevention, Schottenfeld, D. \& Fraumeni J.F.Jr., pp. (813-840), Oxford University Press, New York

Shivji, K.K., Kenny, M.K. \& Wood, R.D. (1992). Proliferating cell nuclear antigen is required for DNA excision repair. Cell, Vol. 69, No. 2, pp. (367-374)

Shivji, M.K., Podust, V.N., Hubscher, U. \& Wood, R.D. (1995). Nucleotide excision repair DNA synthesis by DNA polymerase epsilon in the presence of PCNA, RFC, and RPA. Biochemistry, Vol. 34, No. 15, pp. (5011-5017)

Sijbers, A.M., de Laat, W.L., Ariza, R.R., Biggerstaff, M., Wei, Y.F., Moggs, J.G., Carter, K.C., Shell, B.K., Evans, E., de Jong, M.C., Rademakers, S., de, R.J., Jaspers, N.G., Hoeijmakers, J.H. \& Wood, R.D. (1996). Xeroderma pigmentosum group F caused by a defect in a structure-specific DNA repair endonuclease. Cell, Vol. 86, No. 5, pp. (811-822)

Sinha, R., Peters, U., Cross, A.J., Kulldorff, M., Weissfeld, J.L., Pinsky, P.F., Rothman, N. \& Hayes, R.B. (2005). Meat, meat cooking methods and preservation, and risk for colorectal adenoma. Cancer Res., Vol. 65, No. 17, pp. (8034-8041)

Sinha, R., Rothman, N., Brown, E.D., Salmon, C.P., Knize, M.G., Swanson, C.A., Rossi, S.C., Mark, S.D., Levander, O.A. \& Felton, J.S. (1995). High concentrations of the carcinogen 2-amino-1-methyl-6-phenylimidazo- [4,5-b]pyridine (PhIP) occur in chicken but are dependent on the cooking method. Cancer Res., Vol. 55, No. 20, pp. (4516-4519)

Skjelbred, C.F., Sabo, M., Nexo, B.A., Wallin, H., Hansteen, I.L., Vogel, U. \& Kure, E.H. (2006a). Effects of polymorphisms in ERCC1, ASE-1 and RAI on the risk of colorectal carcinomas and adenomas: A case control study. BMC.Cancer, Vol. 6, No. 1, pp. (175)

Skjelbred, C.F., Saebo, M., Wallin, H., Nexo, B.A., Hagen, P.C., Lothe, I.M., Aase, S., Johnson, E., Hansteen, I.L., Vogel, U. \& Kure, E.H. (2006b). Polymorphisms of the XRCC1, XRCC3 and XPD genes and risk of colorectal adenoma and carcinoma, in a Norwegian cohort: a case control study. BMC.Cancer, Vol. 6, pp. (67)

Skog, K., Steineck, G., Augustsson, K. \& Jagerstad, M. (1995). Effect of cooking temperature on the formation of heterocyclic amines in fried meat products and pan residues. Carcinogenesis, Vol. 16, No. 4, pp. (861-867)

Spitz, M.R., Wu, X., Wang, Y., Wang, L.E., Shete, S., Amos, C.I., Guo, Z., Lei, L., Mohrenweiser, H. \& Wei, Q. (2001). Modulation of nucleotide excision repair 
capacity by XPD polymorphisms in lung cancer patients. Cancer Res., Vol. 61, No. 4, pp. (1354-1357)

Starinsky, S., Figer, A., Ben Asher, E., Geva, R., Flex, D., Fidder, H.H., Zidan, J., Lancet, D. \& Friedman, E. (2005). Genotype phenotype correlations in Israeli colorectal cancer patients. International Journal of Cancer, Vol. 114, No. 1, pp. (58-73), 0020-7136

Stern, M.C., Butler, L.M., Corral, R., Joshi, A.D., Yuan, J.M., Koh, W.P. \& Yu, M.C. (2009). Polyunsaturated fatty acids, DNA repair single nucleotide polymorphisms and colorectal cancer in the Singapore Chinese Health Study. J.Nutrigenet.Nutrigenomics., Vol. 2, No. 6, pp. (273-279)

Stern, M.C., Conti, D.V., Siegmund, K.D., Corral, R., Yuan, J.M., Koh, W.P. \& Yu, M.C. (2007). DNA repair single-nucleotide polymorphisms in colorectal cancer and their role as modifiers of the effect of cigarette smoking and alcohol in the Singapore Chinese Health Study. Cancer Epidemiol.Biomarkers Prev., Vol. 16, No. 11, pp. (23632372)

Stern, M.C., Johnson, L.R., Bell, D.A. \& Taylor, J.A. (2002). XPD codon 751 polymorphism, metabolism genes, smoking, and bladder cancer risk. Cancer Epidemiol.Biomarkers Prev., Vol. 11, No. 10 Pt 1, pp. (1004-1011)

Stern, M.C., Siegmund, K.D., Conti, D.V., Corral, R. \& Haile, R.W. (2006). XRCC1, XRCC3, and XPD polymorphisms as modifiers of the effect of smoking and alcohol on colorectal adenoma risk. Cancer Epidemiol.Biomarkers Prev., Vol. 15, No. 12, pp. (2384-2390)

Stigger, E., Drissi, R. \& Lee, S.H. (1998). Functional analysis of human replication protein A in nucleotide excision repair. J.Biol.Chem., Vol. 273, No. 15, pp. (9337-9343)

Sugasawa, K., Ng, J.M., Masutani, C., Iwai, S., van der Spek, P.J., Eker, A.P., Hanaoka, F., Bootsma, D. \& Hoeijmakers, J.H. (1998). Xeroderma pigmentosum group C protein complex is the initiator of global genome nucleotide excision repair. Mol.Cell, Vol. 2, No. 2, pp. (223-232)

Terry, M.B., Gammon, M.D., Zhang, F.F., Eng, S.M., Sagiv, S.K., Paykin, A.B., Wang, Q., Hayes, S., Teitelbaum, S.L., Neugut, A.I. \& Santella, R.M. (2004). Polymorphism in the DNA repair gene $\mathrm{XPD}$, polycyclic aromatic hydrocarbon-DNA adducts, cigarette smoking, and breast cancer risk. Cancer Epidemiol.Biomarkers Prev., Vol. 13, No. 12, pp. (2053-2058)

Tomkinson, A.E. \& Levin, D.S. (1997). Mammalian DNA ligases. Bioessays, Vol. 19, No. 10, pp. (893-901)

van Maanen, J.M., Moonen, E.J., Maas, L.M., Kleinjans, J.C. \& Van Schooten, F.J. (1994). Formation of aromatic DNA adducts in white blood cells in relation to urinary excretion of 1-hydroxypyrene during consumption of grilled meat. Carcinogenesis, Vol. 15, No. 10, pp. (2263-2268)

Viguier, J., Boige, V., Miquel, C., Pocard, M., Giraudeau, B., Sabourin, J.C., Ducreux, M., Sarasin \& A., Praz, F. (2005). ERCC1 codon 118 polymorphism is a predictive factor for the tumor response to oxaliplatin/5-fluorouracil combination chemotherapy in patients with advanced colorectal cancer. Clin.Cancer.Res., Vol. 11, pp. (6212-6217)

Vogel, U., Olsen, A., Wallin, H., Overvad, K., Tjonneland, A. \& Nexo, B.A. (2005a). Effect of polymorphisms in XPD, RAI, ASE-1 and ERCC1 on the risk of basal cell carcinoma among Caucasians after age 50. Cancer Detect.Prev., Vol. 29, No. 3, pp. (209-214) 
Vogel, U., Overvad, K., Wallin, H., Tjonneland, A., Nexo, B.A. \& Raaschou-Nielsen, O. (2005b). Combinations of polymorphisms in XPD, XPC and XPA in relation to risk of lung cancer. Cancer Lett., Vol. 222, No. 1, pp. (67-74)

Volker, M., Mone, M.J., Karmakar, P., van, H.A., Schul, W., Vermeulen, W., Hoeijmakers, J.H., van, D.R., Van Zeeland, A.A. \& Mullenders, L.H. (2001). Sequential assembly of the nucleotide excision repair factors in vivo. Mol.Cell, Vol. 8, No. 1, pp. (213-224)

Wakasugi, M. \& Sancar, A. (1998). Assembly, subunit composition, and footprint of human DNA repair excision nuclease. Proc.Natl.Acad.Sci.U.S.A, Vol. 95, No. 12, pp. (66696674)

Wakasugi, M. \& Sancar, A. (1999). Order of assembly of human DNA repair excision nuclease. J.Biol.Chem., Vol. 274, No. 26, pp. (18759-18768)

Wang, J., Zhao, Y., Jiang, J., Gajalakshmi, V., Kuriki, K., Nakamura, S., Akasaka, S., Ishikawa, H., Suzuki, S., Nagaya, T. \& Tokudome, S. (2010). Polymorphisms in DNA repair genes $\mathrm{XRCC} 1, \mathrm{XRCC} 3$ and $\mathrm{XPD}$, and colorectal cancer risk: a casecontrol study in an Indian population. J.Cancer Res.Clin.Oncol., Vol. 136, No. 10, pp. (1517-1525)

Weiss, J.M., Weiss, N.S., Ulrich, C.M., Doherty, J.A. \& Chen, C. (2006). Nucleotide excision repair genotype and the incidence of endometrial cancer: effect of other risk factors on the association. Gynecol.Oncol., Vol. 103, No. 3, pp. (891-896)

Weiss, J.M., Weiss, N.S., Ulrich, C.M., Doherty, J.A., Voigt, L.F. \& Chen, C. (2005). Interindividual variation in nucleotide excision repair genes and risk of endometrial cancer. Cancer Epidemiol.Biomarkers Prev., Vol. 14, No. $11 \mathrm{Pt} 1$, pp. (2524-2530)

Wrensch, M., Kelsey, K.T., Liu, M., Miike, R., Moghadassi, M., Sison, J.D., Aldape, K., McMillan, A., Wiemels, J. \& Wiencke, J.K. (2005). ERCC1 and ERCC2 polymorphisms and adult glioma. Neuro.Oncol., Vol. 7, No. 4, pp. (495-507)

Wu, X., Gu, J., Grossman, H.B., Amos, C.I., Etzel, C., Huang, M., Zhang, Q., Millikan, R.E., Lerner, S., Dinney, C.P. \& Spitz, M.R. (2006). Bladder cancer predisposition: a multigenic approach to DNA-repair and cell-cycle-control genes. Am.J.Hum.Genet., Vol. 78, No. 3, pp. (464-479)

Wu, X., Zhao, H., Wei, Q., Amos, C.I., Zhang, K., Guo, Z., Qiao, Y., Hong, W.K. \& Spitz, M.R. (2003). XPA polymorphism associated with reduced lung cancer risk and a modulating effect on nucleotide excision repair capacity. Carcinogenesis, Vol. 24, No. 3, pp. (505-509)

Xing, D., Tan, W., Wei, Q. \& Lin, D. (2002). Polymorphisms of the DNA repair gene XPD and risk of lung cancer in a Chinese population. Lung Cancer, Vol. 38, No. 2, pp. (123-129)

Yang, K., Fang, J.L. \& Hemminki, K. (1998). Abundant lipophilic DNA adducts in human tissues. Mutat Res, Vol. 422, No. 2, pp. (285-295)

Yeh, C.C., Sung, F.C., Tang, R., Chang-Chieh, C.R. \& Hsieh, L.L. (2005). Polymorphisms of the XRCC1, XRCC3, \& XPD genes, and colorectal cancer risk: a case-control study in Taiwan. BMC.Cancer, Vol. 5, pp. (12)

Yeh, C.C., Sung, F.C., Tang, R., Chang-Chieh, C.R. \& Hsieh, L.L. (2007). Association between polymorphisms of biotransformation and DNA-repair genes and risk of colorectal cancer in Taiwan. J.Biomed.Sci., Vol. 14, No. 2, pp. (183-193) 
Yin, J., Vogel, U., Ma, Y., Guo, L., Wang, H. \& Qi, R. (2006). Polymorphism of the DNA repair gene ERCC2 Lys751Gln and risk of lung cancer in a northeastern Chinese population. Cancer Genet.Cytogenet., Vol. 169, No. 1, pp. (27-32)

Yokoi, M., Masutani, C., Maekawa, T., Sugasawa, K., Ohkuma, Y. \& Hanaoka, F. (2000). The xeroderma pigmentosum group C protein complex XPC-HR23B plays an important role in the recruitment of transcription factor IIH to damaged DNA. J.Biol.Chem., Vol. 275, No. 13, pp. (9870-9875)

You, J.S., Wang, M. \& Lee, S.H. (2003). Biochemical analysis of the damage recognition process in nucleotide excision repair. J.Biol.Chem., Vol. 278, No. 9, pp. (7476-7485)

Zienolddiny, S., Campa, D., Lind, H., Ryberg, D., Skaug, V., Stangeland, L., Phillips, D.H., Canzian, F. \& Haugen, A. (2006). Polymorphisms of DNA repair genes and risk of non-small cell lung cancer. Carcinogenesis, Vol. 27, No. 3, pp. (560-567) 


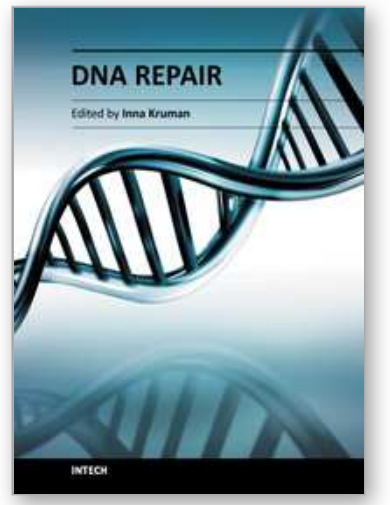

\author{
DNA Repair \\ Edited by Dr. Inna Kruman
}

ISBN 978-953-307-697-3

Hard cover, 636 pages

Publisher InTech

Published online 07, November, 2011

Published in print edition November, 2011

The book consists of 31 chapters, divided into six parts. Each chapter is written by one or several experts in the corresponding area. The scope of the book varies from the DNA damage response and DNA repair mechanisms to evolutionary aspects of DNA repair, providing a snapshot of current understanding of the DNA repair processes. A collection of articles presented by active and laboratory-based investigators provides a clear understanding of the recent advances in the field of DNA repair.

\title{
How to reference
}

In order to correctly reference this scholarly work, feel free to copy and paste the following:

Rikke Dalgaard Hansen and Ulla Vogel (2011). Polymorphisms in Nucleotide Excision Repair Genes and Risk of Colorectal Cancer: A Systematic Review, DNA Repair, Dr. Inna Kruman (Ed.), ISBN: 978-953-307-697-3, InTech, Available from: http://www.intechopen.com/books/dna-repair/polymorphisms-in-nucleotide-excisionrepair-genes-and-risk-of-colorectal-cancer-a-systematic-review

\section{INTECH}

open science | open minds

\section{InTech Europe}

University Campus STeP Ri

Slavka Krautzeka 83/A

51000 Rijeka, Croatia

Phone: +385 (51) 770447

Fax: +385 (51) 686166

www.intechopen.com

\section{InTech China}

Unit 405, Office Block, Hotel Equatorial Shanghai

No.65, Yan An Road (West), Shanghai, 200040, China

中国上海市延安西路65号上海国际贵都大饭店办公楼 405 单元

Phone: +86-21-62489820

Fax: $+86-21-62489821$ 
(C) 2011 The Author(s). Licensee IntechOpen. This is an open access article distributed under the terms of the Creative Commons Attribution 3.0 License, which permits unrestricted use, distribution, and reproduction in any medium, provided the original work is properly cited. 